\title{
A Model for Adoption of ICT in Jordanian Higher Education Institutions: An Empirical Study
}

\author{
Mohammad Khasawneh $^{1}$ and Huda Ibrahim ${ }^{2}$ \\ ${ }^{1}$ The World Islamic Sciences and Education University, Amman, Jordan \\ ${ }^{2}$ University Utara Malaysia (UUM), Sintok, Malasyia
}

\begin{abstract}
Information and Communication Technology (ICT) plays a major role in modern universities by facilitating and improving the educational system to be in line with the information technology age. The higher education sector in Jordan is considered as one of the most influential sectors that develop the country. In striving towards a competitive institution, a university must enhance teaching and learning process related to the advancement of ICT. However, this study attempts to focus on the adoption of ICT in Jordanian public universities among the academic staff, with the concern on the factors influencing their acceptance of ICT in the educational system. Moreover, the study attempts to build a conceptual model to the Jordanian case according to the results of factor analysis. A self-administrated survey was conducted on 500 teaching staff selected from public universities in Jordan. A total of 415 participants (83\%) have responded, and series of data analyses of variables measurement for reliability and validity test of predictors were performed. The results of the analysis, however, contribute a new model which is considered as a novel model in such studies.
\end{abstract}

Keywords: Information and Communication Technology (ICT); adoption; Higher Education; Jordan.

\section{Introduction}

The new and rapidly growth of ICT has changed the face of the world. ICT has become the main influential determinant in economic, social, and human development (Dertouzos, 1997), and is being considered as the umbrella for the communication and networking devices and software with applications (Jain, 2006). The Hashemite Kingdom of Jordan (HKJ) is one of the highly developed Arab countries in the Middle East. The King and the Government have sponsored many initiatives to encourage the diffusion of technologies in the country that not only possessing the geographical advantage, but also often seeking to develop technological workforces to increase the standard of living and economic productivity (Al-
Jaghoub and Westrup, 2003). Jordan focuses on the higher education sector and

universities significantly in regards to the development of human resources in the country.

The adoption and diffusion of educational technologies that leverage ICT and the Internet has provided an unprecedented opportunity for improving higher education around the world (Davis and Wong, 2007). Therefore, educational technologies must become more popular among developing nations which seek economic improvement (Khasawneh et al., 2011). In fact, the educational technology is becoming more universal at an increasing rate as most firms recognize the needs to prepare the ICT professionals for the global environment (Margavio, 2005).

Copyright (C) 2012 Mohammad Khasawneh and Huda Ibrahim. This is an open access article distributed under the Creative Commons Attribution License unported 3.0, which permits unrestricted use, distribution, and reproduction in any medium, provided that original work is properly cited. Contact author: Mohammad Khasawneh E-mail: m_khasa@yahoo.com 
In the matter of fact, the higher education sector in Jordan plays a critical role in the growth the national economy because the individuals have strong needs and interests in education to develop their knowledge and skills to become competitive and knowledge workers in the global markets. Unfortunately, until now there is a lack of ICT usage among the universities' academic staff in Jordanian higher educational institutions (Al-Mobaideen, 2009). Apart from that, the adoption and usage of ICT in universities in teaching and learning process are still limited among the academicians (Patnaik, 2001), in which they have lack knowledge, skills, motivation, and interests in using ICT in facilitating their works (Jawarneh et al., 2007; Qudais et al., 2010). From the perspective of ICT usage, this study makes an attempt in bridging the digital divide between developed and developing countries in the use of ICT in the education and learning process through Jordanian higher education institutions. The optimum using of ICT by academic staff in the universities will develop the quality of alumnus and improve the teaching and learning process in creating new generation capable and competitive in the global market.

\section{Literature Review}

Midgley and Dowling (1978) defined innovativeness as the time to which an individual is receptive to new ideas and product and makes adoption decisions independently of the communicated experience of others. In relation, the diffusion of innovation is a communication process they define innovativeness as a personality trait they call 'innate innovativeness' operating at the most abstract, global level of conceptualization to influence a variety of domain-specific behaviors, including the relative early purchase of new products (Midgley and Dowling, 1978).

Also, they proposed an intermediary level of product-category specific innovativeness which mediates the effects of innate innovativeness along with a variety of inter-individual difference variables and situational factors on actual innovation adoption (Midgley and Dowling, 1978). This definition opened up a new vista for studying innovative behavior as this view of innovativeness is postulated to all product classes. This led to propose a new model to study innovativeness as shown in Figure 1 below.

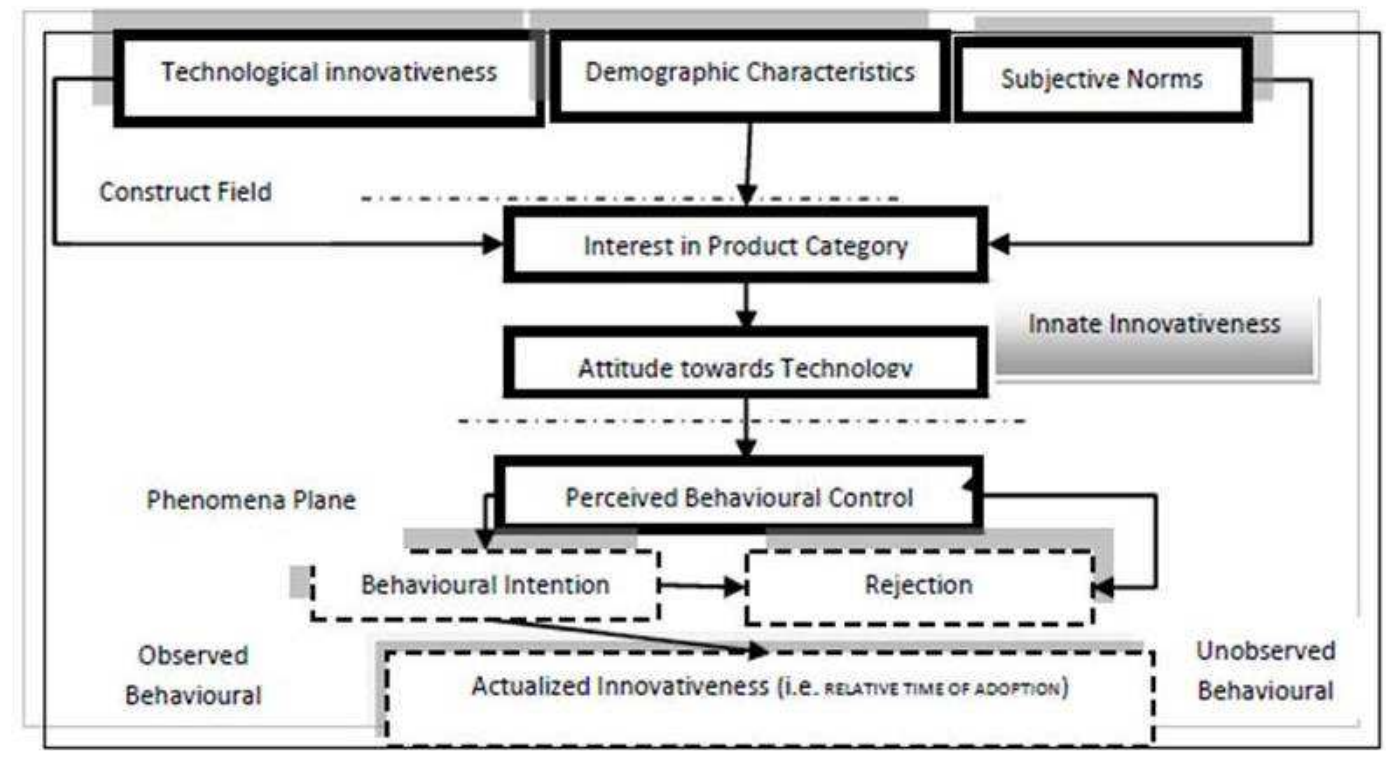




\section{Fig 1. Research Model}

The above model defines the innovativeness construct in a more comprehensible manner, suggests categories of variables that could be used to operationalize the model and provides examples of variables in each category. The model integrates the innovator (academician), the product (ICT), and the situation specificity as determinants of innovative behavior. As shown, the model is divided into three parts: (i) the construct field, (ii) phenomena plane, and (iii) (un)observed behavior. The construct field comprises into (a) demographic variables, (b) technological innovativeness, and (c) subjective norms. The phenomenon plane starts with an interest in the product category which is bolstered or dampened by intervening variables pertaining to product or technology characteristics. All these lead to the next phenomenon by intervening previewed behavior control factors that affected in the behavioral intention (BI).

This proposed model brings together many of the factors of greatest relevance identified in previous literature such as attitude towards technology (ATT), subjective norms (SN), and perceived behavioral control (PBC). The model shows the importance and recognition of external situational and environment factors commonly acknowledged in the literature as influencing ICT adoption, and which are missing from the general diffusion of innovation developed for innovations in general. The proposed model presents many factors which are considered impact upon the individual's adoption of ICT in addition to demographic variables.

The purpose of this study is to identify the factors that affect on the adoption of ICT at the institutional higher education in Jordan. The initial model is framed within the Diffusion of Innovation (DOI) (Rogers, 1995), and enhanced by others such as Theory of Planned Behavior (TPB) (Ajzen, 1991), and the Decomposed Theory of Planned Behavior (DTPB) (Taylor and
Todd, 1995a). The model, and its corresponding hypotheses, incorporates the constructs that are considered to be most relevant to adoption in Jordan. These include the following factors:

- Demographic variables such as gender, age, higher education degree, place of obtaining higher education degree, major, and experience.

- ATT such as Rogers' attributes; relative advantage (RA), compatibility (Compt), complexity (Compx), trialability (Trial), and observability (Observ) (Rogers, 1995).

- SN such as word of mouth (WoM), and mass media channels (MMC) (Ajzen, 1991).

- PBC such as self efficacy (SE), technology facilitating conditions (TFC), resource facilitating condition (RFC), and government facilitating condition (GFC) (Taylor and Todd, 1995a, 1995b).

\section{Factor Analysis}

A wide series of factor analysis in the shape of Principle Component Analysis (PCA) is utilized to test for both the convergent and discriminate validity of the measurements. Factor analysis is an interdependent technique and the primary purpose of using it, is to define the underlying structure among the variables in the analysis (Zikmund, 2003; Hair et al., 2006). PCA and principal factors are the most commonly used (Tabachnick and Fidell, 2007). The aims that this study seeks to achieve from the factor analysis technique are discussed in the subsequent paragraphs.

The first aim is to analyze the scale items of each construct and verify their discriminate validity. Discriminate validity concerns with the ability of a measurement item to differentiate between the objects being measured (Davis, 1989). Malhotra (2004) puts it in another way, saying that discriminate validity aimed to identify new 
uncorrelated variables to be used in subsequent multivariate analyses such as regression.

The second aim is to reduce the large number of interrelated variables to a small number of underlying factors that ensures the construct validity. It addresses the question of what construct or characteristic the scale is, in fact, measuring (Malhotra, 2004).

The third aim is to explain the interrelations between the constructs and the variables measuring them. It is concerned with whether constructs' items form distinct constructs (Davis, 1989). The fourth aim is to identify a smaller set of salient variables for use in subsequent multivariate analysis (Malhotra, 2004). Lastly, factor analysis may be utilized to meet the statistical assumptions of various models (Zikmund, 2003).

\section{Factors Analysis for Criterion Variable BI}

The four items of the BI construct assumed were subjected to PCA, Varimax with Kaiser Normalization as rotation method shown in Table 1, to determine how many dimensions those items which measure BI will converge along.

Table 1: PCA Result Component Matrix and Factor Loading: BI

\begin{tabular}{|l|l|c|}
\hline \multicolumn{1}{|c|}{ Constructs } & \multicolumn{1}{|c|}{ Items } & \multicolumn{1}{|c|}{$\begin{array}{c}\text { Component,1 } \\
\text { Loading }\end{array}$} \\
\hline Behavioral Intention & $\begin{array}{l}\text { BI_Q1: Given the chance, I predict that I would } \\
\text { Uigenvalues: } 2.626\end{array}$ & 0.817 \\
\cline { 2 - 3 } $\begin{array}{l}\text { The variance } \\
\text { explained: } 65.628 \%\end{array}$ & $\begin{array}{l}\text { BI_Q2: I will strongly recommended others to } \\
\text { KMe ICT in the teaching system }\end{array}$ & 0.746 \\
\cline { 2 - 3 } $\begin{array}{l}\text { Cronbach's Alpha: } \\
0.83\end{array}$ & $\begin{array}{l}\text { BI_Q3: My favorable intention would be to use } \\
\text { technologies in the education system rather } \\
\text { than traditional way in the teaching system }\end{array}$ & \\
\cline { 2 - 3 } & $\begin{array}{l}\text { BI_Q4: I plan to use ICT in the teaching and } \\
\text { learning system }\end{array}$ & 0.844 \\
\hline
\end{tabular}

Consequently, the result of factor analysis in this construct revealed the following:

- The presence of one component with eigenvalues of 2.63 exceeding the recommended value of one.

- The factor analysis provided a solution in one component which explained $65.6 \%$ of the variance.

- An assessment of the Kaiser-Meyer-Olkin (KMO) value was of 0.801 , which shows that the sampling adequacy for factor analysis was appropriate and the Barlett's Test of Sphericity reached statistical significance, supporting the factorability of the correlation matrix.

The interpretation of this component was consistent with previous research on the BI scale. In addition, the result of this analysis supports the use of selected items as a scale of BI as suggested by the scale (Mathieson,
1991; Venkatesh and Davis, 2000; Gardner and Amoroso, 2004; Shih and Fang, 2004).

Direct Psychosocial Determinants of BI

In this study, exploratory factor analysis (EFA) was employed to identify the factors underlying direct predictors (ATT, SN_WoM, MMC, and PBC). In this case, the factor extraction method of Principal-Axis Factoring Analysis (PFA) was selected because it is useful in determining the number of factors necessary to represent the data (Coakes and Steed, 2003).

Factor analysis revealed the presence of four components with eigenvalues exceeding one. In addition, the required 4 factors were retained on the measurement for the three direct factors conceptually and theoretically assumed to be the direct predictors of BI. The interpretation of the four components was consistent with the theory of TPB on the direct scale of BI (Fishbein and Ajzen, 1975; Ajzen, 1991; 
Taylor and Todd, 1995a; Taylor and Todd, items used to measure BI and their loading 1995b). In conjunction, Table 2 shows the onto four different components as follows;

Table 2: PFA Result: Factors Underlying Direct Attributes of BI

\begin{tabular}{|c|c|c|c|c|}
\hline \multirow[t]{2}{*}{ Item coding } & \multicolumn{4}{|c|}{ Factors } \\
\hline & ATT & SN_WoM & MMC & PBC \\
\hline $\begin{array}{l}\text { ATT_Q2: If I were to use ICT in the teaching system, the quality of } \\
\text { my work would improve }\end{array}$ & 0.569 & & & \\
\hline $\begin{array}{l}\text { ATT_Q3: If I were to use ICT in the teaching system, it would } \\
\text { enhance my effectiveness on my job }\end{array}$ & 0.507 & & & \\
\hline $\begin{array}{l}\text { ATT_Q4: If I were to use ICT in the teaching system, it would make } \\
\text { my job easier }\end{array}$ & 0.294 & & & \\
\hline $\begin{array}{l}\text { ATT_Q1: If I were to use ICT in the teaching system, it would } \\
\text { enable me to accomplish my tasks more quickly }\end{array}$ & 0.276 & & & \\
\hline $\begin{array}{l}\text { WoM_Q2: My referents (peers, colleagues, friends, and family) } \\
\text { would think that I should try out ICT in the educational system. }\end{array}$ & & 0.961 & & \\
\hline $\begin{array}{l}\text { SN_Q3: Most people who are important to me would think that I } \\
\text { should try out the technologies in the educational system. }\end{array}$ & & 0.928 & & \\
\hline $\begin{array}{l}\text { WoM_Q3: Generally speaking, I want to do what my referent } \\
\text { thinks I should do }\end{array}$ & & 0.924 & & \\
\hline $\begin{array}{l}\text { WoM_Q1: My referents (peers, colleagues, friends, family) would } \\
\text { think that I should use ICT in the educational system }\end{array}$ & & 0.908 & & \\
\hline $\begin{array}{l}\text { SN_Q2: The people who influence my decisions would think that I } \\
\text { should use ICT in the educational system }\end{array}$ & & 0.903 & & \\
\hline $\begin{array}{l}\text { WoM_Q6: Generally speaking, I want to do what my opinion } \\
\text { leaders think I should do }\end{array}$ & & 0.881 & & \\
\hline $\begin{array}{l}\text { SN_Q4: The people who influence my decisions would think that I } \\
\text { should try out the technologies in the educational system }\end{array}$ & & 0.877 & & \\
\hline $\begin{array}{l}\text { SN_Q1: Most people who are important to me would think that I } \\
\text { should use ICT in the educational system }\end{array}$ & & 0.863 & & \\
\hline $\begin{array}{l}\text { WoM_Q4: My opinion leaders would think that I should use ICT in } \\
\text { the educational system }\end{array}$ & & 0.840 & & \\
\hline $\begin{array}{l}\text { WoM_Q5: My opinion leaders would think that I should try out ICT } \\
\text { in the educational system }\end{array}$ & & 0.839 & & \\
\hline $\begin{array}{l}\text { MMC_Q4: I read/saw news report that using ICT in the } \\
\text { educational system was a good way to manage the teaching and } \\
\text { learning process }\end{array}$ & & & 0.701 & \\
\hline MMC_Q5: I want to do what the media think I should do & & & 0.694 & \\
\hline $\begin{array}{l}\text { MMC_Q2: The media and advertising consistently recommend } \\
\text { using ICT in the educational system }\end{array}$ & & & 0.541 & \\
\hline $\begin{array}{l}\text { MMC_Q1: The media are full of report, articles, and news } \\
\text { suggesting that using ICT in the educational system is a good idea }\end{array}$ & & & 0.492 & \\
\hline $\begin{array}{l}\text { PBC_Q2: I have the resources necessary to make use of ICT in the } \\
\text { teaching system }\end{array}$ & & & & \\
\hline $\begin{array}{l}\text { PBC_Q3: I have the knowledge necessary to make use of ICT in the } \\
\text { education system }\end{array}$ & & & & -0.860 \\
\hline $\begin{array}{l}\text { PBC_Q4: I have the ability to make use of ICT in the education } \\
\text { system }\end{array}$ & & & & -0.844 \\
\hline PBC_Q1: I would be able to use ICT in the educational system & & & & -0.748 \\
\hline $\begin{array}{l}\text { PBC_Q5: Using ICT in the teaching system would be entirely } \\
\text { within my control }\end{array}$ & & & & -0.704 \\
\hline Eigenvalue & 12.343 & 2.087 & 1.623 & 1.203 \\
\hline Variance explained & 50.395 & 7.115 & 5.213 & 3.185 \\
\hline Cronbach's Alpha & 0.73 & 0.98 & 0.75 & 0.91 \\
\hline
\end{tabular}

Total Variance Extracted by three factors 65.909\%; KMO 0.947; Barlett's Test<.001

The set of 23 items comprising four constructs (ATT, SN_WoM, MMC, and PBC) were subjected to factor analysis and the solution was rotated using rotational method with the Oblimin with Kaiser Normalization approach. The result of the analysis indicates that: 
- Respondents involved in the study sample are able to distinguish the variation among the four of BI functions (direct determinants) or predictors of BI whereby this findings in agreement with the DOI, TPB, and the DTPB of the direct predictors.

- The assessment of direct determinants of BI construct, according to respondents, seemed to be through four predictors; (ATT, SN_WoM, MMC, and PBC).

- An assessment of the KMO value was of 0.947 which shows that the sampling adequacy for factor analysis was appropriate and the Barlett's Test of Sphericity reached statistical significance, supporting the factorability of the correlation matrix.

\section{Factor Analysis of Salient Variables}

The adoption's model that combines the three independent variables (ATT, SN, and $\mathrm{PBC}$ ) to explain the intention to use innovation performs well by exceeding the $40 \%$ in the explaining the intention that was achieved by several other theoretical models in the fields of information systems. Evidence of efficacy was drawn from metaanalytic review of 185 independent studies, in which they demonstrated that TPB has accounted for $27 \%$ to $39 \%$ of the variance in BI (Armitage and Conner, 2001).

This study uses three adoption theories in proposing a new model related to the area of the study. The theories are DOI (Rogers, 1995), TPB (Ajzen, 1991), and DTPB (Taylor and Todd, 1995a, 1995b).

Contrast with expectations, the results of SN predictor showed difference with TPB (Ajzen, 1991). The findings of PFA shown in Table 3 reveal that only two factors out of three predetermined variables related to the SN of TPB were statistically extracted by the study. Results of the PFA demonstrated that there are two normative beliefs components were found related to the BI which are subjective norms with the personal channels (SN_WoM) and the MMC.

Table 3: PFA Result: Type of Interaction's Norms

\begin{tabular}{|l|l|l|l|}
\hline Coding & SN_WoM & MMC & A \\
\hline SN_Q3 & 0.943 & & \\
WoM_Q2 & 0.942 & & \\
WoM_Q3 & 0.928 & & \\
WoM_Q6 & 0.911 & & \\
SN_Q2 & 0.901 & & \\
SN_Q1 & 0.895 & & \\
WoM_Q5 & 0.886 & & \\
WoM_Q4 & 0.885 & & \\
SN_Q4 & 0.882 & & \\
WoM_Q1 & 0.874 & 0.731 & \\
\hline MMC_Q4 & & 0.670 & \\
MMC_Q2 & & 0.654 & \\
MMC_Q5 & & 0.568 & \\
MMC_Q1 & & 1.91 & 2.00 \\
\hline Eigenvalue & 8.90 & 9.39 & \\
Variance Explained & 58.23 & 0.75 & \\
Cronbach's Alpha & 0.98 & & \\
\hline
\end{tabular}

(a) Total Variance Extracted by two factors 70.134\%; KMO = 0.942; Barlett's Test <.001

(b) Extraction Method: Principal Axis Factoring;

(c) Rotation Method: Oblimin with Kaiser Normalization

Rogers' five attributes explain the educational technology characteristics which affect academic staffs' attitude toward the use of these technologies
(Rogers, 1995). As study expects, the results of the PFA shown in Table 4 reveal that all the factors which are defined in DOI appear 
as separated factors. The factors are RA, Comp, Compx, Trial), and Observ.

Table 4: PFA Result: ICT Attributes

\begin{tabular}{|c|c|c|c|c|c|c|}
\hline Items & RA & Compt & Compx & Trial & Observ & 6 \\
\hline $\begin{array}{c}\text { RA_Q4: If I were to use ICT in the teaching system, } \\
\text { it would make my job easier } \\
\text { RA_Q3: If I were to use ICT in the teaching system, } \\
\text { it would enhance my effectiveness on my job } \\
\text { RA_Q5: Using ICT in the education system gives me } \\
\text { greater control over my work } \\
\text { RA_Q2: If I were to use ICT in the teaching system, } \\
\text { the quality of my work would improve } \\
\text { RA_Q1: If I were to use ICT in the teaching system, } \\
\text { it would enable me to accomplish my tasks more } \\
\text { quickly }\end{array}$ & $\begin{array}{l}0.619 \\
0.514 \\
0.358\end{array}$ & & & & & \\
\hline $\begin{array}{c}\text { Compt_Q1: If I were to use ICT in the teaching } \\
\text { system, it would be compatible with most aspect of } \\
\text { my work } \\
\text { Compt_Q2: If I were to use ICT in the teaching } \\
\text { system, it would fit my work style } \\
\text { Compt_Q3: If I were to use ICT in the teaching } \\
\text { system, it would fit well with the way I like to work }\end{array}$ & & $\begin{array}{l}-0.917 \\
-0.820 \\
-0.759\end{array}$ & & & & \\
\hline $\begin{array}{c}\text { Compx_Q1: Training and learning to using ICT in } \\
\text { the teaching system would be easy for me } \\
\text { Compx_Q3: It would be easy for me to become } \\
\text { skilful at using ICT in the teaching system } \\
\text { Compx_Q2: Overall, if I were to use ICT in the } \\
\text { teaching system, it would be easy to use } \\
\text { Compx_Q4: Using ICT in the education system } \\
\text { requires a lot of mental effort }\end{array}$ & & & $\begin{array}{l}0.767 \\
0.681 \\
0.617 \\
0.489\end{array}$ & & & \\
\hline $\begin{array}{c}\text { Trial_Q3: I want to be permitted to use ICT in the } \\
\text { teaching system, on a trial basis long enough to see } \\
\text { what it can do } \\
\text { Trial_Q1: Before deciding on whether or not to use } \\
\text { ICT in the teaching system, I want to be able to use } \\
\text { it on a trial basis } \\
\text { Trail_Q2: Before deciding on whether or not to use } \\
\text { ICT in the teaching system, I want to be able to } \\
\text { properly try it out }\end{array}$ & & & & 0.706 & & \\
\hline $\begin{array}{c}\text { Observ_Q2: I will use ICT in the teaching system, } \\
\text { when I have seen others using it } \\
\text { Observ_Q5: I will wait until other academicians } \\
\text { start use it } \\
\text { Observ_Q6: I will use ICT in the teaching system, } \\
\text { when other academicians have successful } \\
\text { experience of using it } \\
\text { Observ_Q4: I will use ICT in the education } \\
\text { technology if it become popular }\end{array}$ & & & & & $\begin{array}{l}0.730 \\
0.693 \\
0.690\end{array}$ & \\
\hline $\begin{array}{c}\text { Eigenvalue } \\
\text { Variance Explained } \\
\text { Cronbach's Alpha }\end{array}$ & $\begin{array}{c}6.92 \\
30.20 \\
0.74\end{array}$ & $\begin{array}{l}1.98 \\
6.77 \\
0.92\end{array}$ & $\begin{array}{l}1.90 \\
6.56 \\
0.69\end{array}$ & $\begin{array}{l}1.52 \\
4.66 \\
0.71\end{array}$ & $\begin{array}{l}1.15 \\
3.99 \\
0.91\end{array}$ & $\begin{array}{l}1.09 \\
1.88\end{array}$ \\
\hline
\end{tabular}

(a) Total Variance Extracted by the five factors $54.085 \%$; KMO =0 .870; Barlett's Test <.001.

(b) Observ_1, Observ_Q3 and Observ_Q7 dropped in the second round of factor analysis.

The last predictor of the proposed model is control belief, in which the results of this factor are consistent with the DTPB (Taylor and Todd, 1995a, 1995b), decomposed into two dimensions; SE and facilitating conditions (FC). The FC construct was broken down into three other dimensions, which include TFC, RFC, and GFC. As expectation, the results of the PFA shown in 
Table 5 reveal all the factors that defined in

DTPB appear as separated factors.

\section{Table 5: PFA Result: Control Belief}

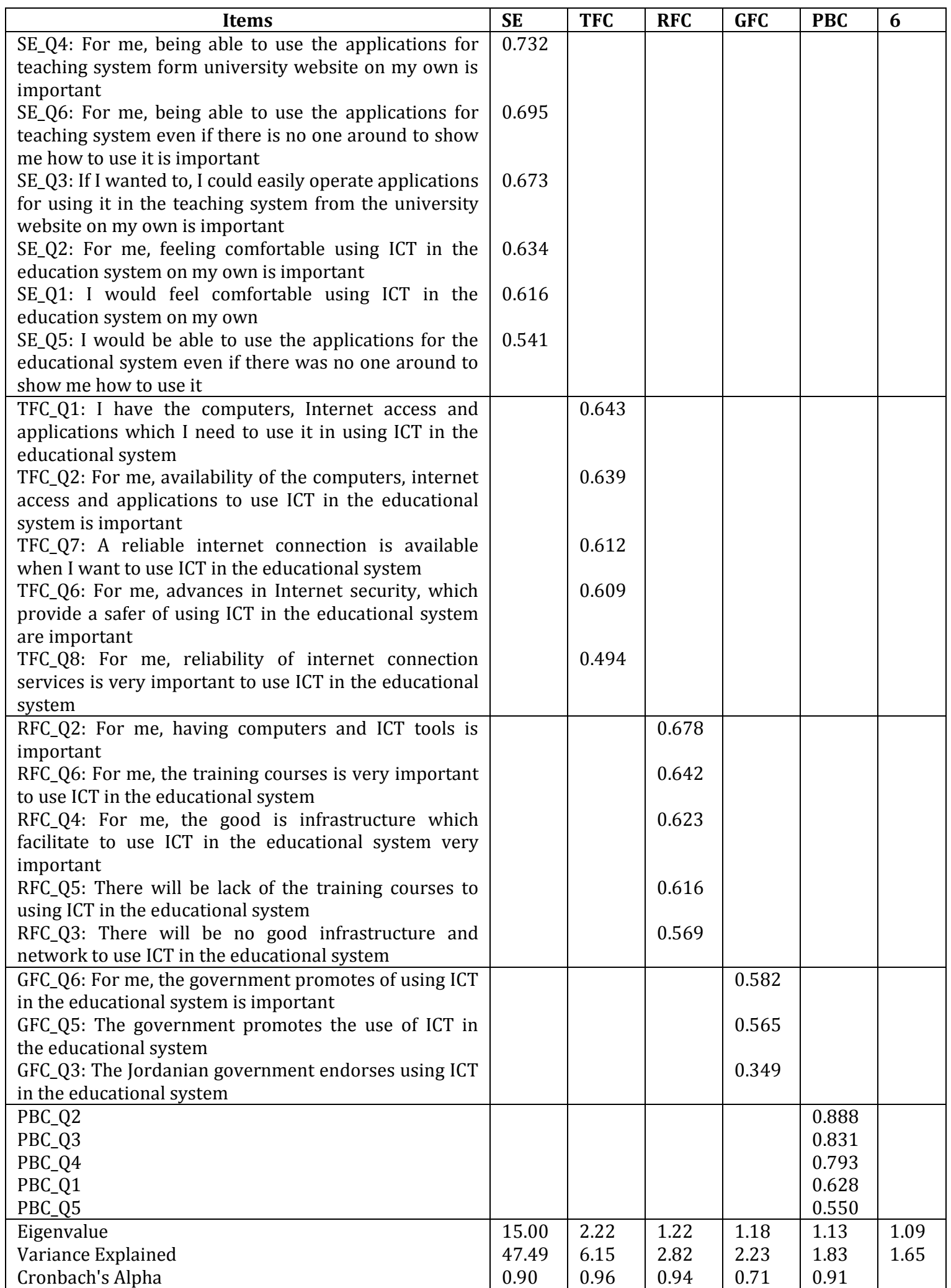

(a) Total of variance explained $=62.198$ 
This study is motivated by the need to inform researchers and practitioners about what are the factors that affect academic staff to adopt or reject ICT in Jordanian institutional and encourage faster and more efficient adoption. This is a theory building investigation to explore the factors that are likely to influence the use of ICT among staff in the Jordanian higher education institutions. However, there is no known study that has empirically investigated such factors. Little attention has been paid in the literature to the adoption of ICT in the context of developing countries in general. As the objective of the present study is to consider academic staffs' behavior pertaining to the adoption of ICT, we carefully chose the variables that the literature has shown to be important in explaining the adoption of ICT, which are amenable to statistical analysis.

\section{Conclusion}

The study is considered novel in the developing countries, Jordan and the Arab world in particular, which share the same culture, language and religion. It makes a significant contribution to theory and academic understanding of the adoption in areas of IS, and specifically ICT usage in higher education institutions, Jordanian context. As a summary, understanding the behavioral aspect of adoption is important to both researchers and industry players. The findings of the current research contribute to theoretical modelling by modifying the IS adoption theories in relation to a new application area that may give new insights into the theory. It is also proposed that this study improves a successful adoption of the particular services (ICT) that are supported by new technologies by deepening the knowledge about factors which inhibit or facilitate the adoption among the developing nation and the Arab countries in particular, as these countries share similar culture, religion, and speak the same language. Eventually, the proposed research model will be the authority for all universities to encourage the adoption and utilization of ICT in the educational and learning process in Jordan and all Arab countries.

\section{References}

Ajzen, I. (1991). "The Theory of Planned Behavior," Organizational behavior and human decision processes, 50(2), 179-211.

Al-Jaghoub, S. \& Westrup, C. (2003). "Jordan and ICT-Led Development: Towards a Competition State," Information Technology and People, 16(1), 93-110.

Al-Mobaideen, H. O. (2009). "ICT Diffusion in Jordanian Universities," European and Mediterranean Conference on Information Systems 2009 (EMCIS2009) July 13-14 2009, Crowne Plaza Hotel, Izmir.1-21.

Armitage, C. J. \& Conner, M. (2001). "Efficacy of the Theory of Planned Behaviour: A Meta Analytic Review," British Journal of Social Psychology, 40(4), 471499.

Coakes, S. J. \& Steed, L. G. (2003). SPSS: Analysis without Anguish: Version 11.0 for Windows, John Wiley and Sons Inc. Australia.

Davis, F. D. (1989). "Perceived Usefulness, Perceived Ease of Use, and User Acceptance of Information Technology," MIS quarterly, 13(3), 319-340.

Davis, R. \& Wong, D. (2007). "Conceptualizing and Measuring the Optimal Experience of the eLearning Environment," Decision Sciences Journal of Innovative Education, 5(1), 97-126.

Dertouzos, M. L. (1997). What Will Be: How the New World of Information Will Change Our Lives, San Francisco: Harper Collins.

Fishbein, M. \& Ajzen, I. (1975). 'Belief, Attitude, Intention and Behavior: An Introduction to Theory and Research,' USA: Addison-Wesley Reading, MA.

Gardner, C. \& Amoroso, D. (2004). Development of an Instrument to Measure the Acceptance of Internet Technology by Consumers," Paper presented at the System Sciences, 2004. Proceedings of the 37th Annual Hawaii International Conference, 110. 
Hair, J., Black, W., Babin, B., Anderson, R. \& Tatham, R. (2006). 'Multivariate Data Analysis (6 ed.': Upper Saddle River, NJ: Pearson Education Inc.

Jain, P. (2006). "Empowering African's Development Using ICT in a Knowledge Management Approach," The Electronic Library, 24(1): 51-67.

Jawarneh, T. Y., El-Hersh, A. H. \& Khazaleh, T. M. (2007). "Vocational Education Teachers' Adoption of Information and Communications Technology (ICT) in the Jordanian Secondary Vocational Schools," Umm Al-Qura University. Journal of Educational and Social Sciences and Humanities, 19(2), 11-56.

Khasawneh, A., Khasawneh, M., Bsoul, M., Idwan, S. \& Turan, A. H. (2011). 'Models for Using Internet Technology to Support Flexible E-Learning,' Int. J. Management in Education. [Accepted].

Malhotra, N. (2004). 'Marketing Research: An Applied Orientation (4 ed.),' Upper Saddle River, New Jersey, USA: Pearson Prentice-Hall.

Margavio, T., Hignite, M., Moses, D. \& Margavio, G. W. (2005). "Multicultural Effectiveness Assessment of Students in IS Courses," Journal of Information Systems Education, 16(4), 421.

Mathieson, K. (1991). "Predicting User Intentions: Comparing the Technology Acceptance Model with the Theory of Planned Behavior," Information systems research, 2(3), 173-191.

Midgley, D. F. \& Dowling, G. R. (1978). "Innovativeness: The Concept and its Measurement," Journal of Consumer Research, 4(4), 229.

Patnaik, J. (2001). Higher Education in Information Age (1 ed.),' Authors press.

Qudais, M. A., Al-Adhaileh, M. \& Al-Omari, A. (2010). "Senior Faculty Members' Attitudes in Jordanian Universities towards Using Information and Communication
Technology," International Arab Journal of e-Technology, 1(4), 135-141.

Rogers, E. M. (1995). Diffusion of innovations (4 ed.), New York: Free Press.

Shih, Y.- Y. \& Fang, K. (2004). "The Use of a Decomposed Theory of Planned Behavior to Study Internet Banking In Taiwan," Internet Research, 14(3) 213-223.

Tabachnick, B. G. \& Fidell, L. S. (2007). Using Multivariate Statistics, New York: Allyn and Rose.

Taylor, S. \& Todd, P. A. (1995a). "Understanding Information Technology Usage: A Test of Competing Models," Information systems research, 6(2), 144176.

Taylor, S. \& Todd, P. A. (1995b). "Decomposition and Crossover Effects in the Theory of Planned Behavior: A Study of Consumer Adoption Intentions," International Journal of Research in Marketing, 12(2), 137-155.

Venkatesh, V. \& Davis, F. D. (2000). "A Theoretical Extension of the Technology Acceptance Model: Four Longitudinal Field Studies," Management science, 46(2) 186204.

Zikmund, W. G. (2003). 'Business Research Methods Cincinnati, OH: Thomson/SouthWestern: ISBN 0-03-025817-0 10. 